\title{
Mothbean: A Potential Summer Crop for the Southern Great Plains
}

\author{
Gurjinder S. Baath ${ }^{1}$, Brian K. Northup ${ }^{2}$, Prasanna H. Gowda ${ }^{2}$, Kenneth E. Turner ${ }^{2}$, \\ Alex C. Rocateli ${ }^{1}$ \\ ${ }^{1}$ Department of Plant and Soil Sciences, Oklahoma State University, Stillwater, OK, USA \\ ${ }^{2}$ Grazinglands Research Laboratory, USDA-ARS, El Reno, OK, USA \\ Email: *gbaath@okstate.edu
}

How to cite this paper: Baath, G.S., Northup, B.K., Gowda, P.H., Turner, K.E. and Rocateli, A.C. (2018) Mothbean: A Potential Summer Crop for the Southern Great Plains. American Journal of Plant Sciences, 9, 1391-1402.

https://doi.org/10.4236/ajps.2018.97101

Received: February 10, 2018

Accepted: June 8, 2018

Published: June 11, 2018

Copyright $\odot 2018$ by authors and Scientific Research Publishing Inc. This work is licensed under the Creative Commons Attribution International License (CC BY 4.0).

http://creativecommons.org/licenses/by/4.0/

\begin{abstract}
Low nutritive value of available warm-season grasses during July through September limits the production of yearling stocker cattle in the southern Great Plains (SGP). There has been a continual exploration of species with the capacity to provide high quality forage during summer. Mothbean (Vigna aconitifolia [Jacq.] Marechal), a short-duration, drought tolerant crop is a promising choice for the SGP. This preliminary study evaluated the potential of mothbean as a summer crop for forage, grain or green manure. Results of this study with 10 mothbean lines from a range of geographic locations suggested that crop could be harvested 100 days after planting with dry biomass yield range of $7.3-18.1 \mathrm{Mg} \cdot \mathrm{ha}^{-1}$. Mothbean forage contained 10.8\% - 14.6\% crude protein (CP), 32.0\% - 41.7\% neutral detergent fiber (NDF), $20.7 \%$ $29.6 \%$ acid detergent fiber (ADF), and $73 \%-84 \%$ in vitro true digestibility (IVTD) at maturity. Grain yield of the 10 mothbean lines varied from 91 to $1040 \mathrm{~kg} \cdot \mathrm{ha}^{-1}$. The 10 tested lines generated a high amount of nitrogen $(\mathrm{N})$ rich biomass at maturity with total accumulated $\mathrm{N}$ of $163-316 \mathrm{~kg} \cdot \mathrm{ha}^{-1}$ and a C:N ratio of 16:1 to 22:1. Overall, performance indicators suggested that mothbean has considerable potential as an alternative crop for production of forage, grain, or green manure when grown as summer crop in rotation with winter wheat. Future research should focus on evaluating mothbean within different crop settings to define its capacity as green manure or summer forage to support production of stocker cattle in the SGP.
\end{abstract}

\section{Keywords}

Forage Quality, Forage Yield, Grain Legumes, Green Manure, Drought Tolerance 


\section{Introduction}

The production of weight gains by yearling stocker cattle in the US SGP depends on the availability of grazing pastures of winter wheat (Triticum aestivum L.) during fall and spring, perennial warm-season grasses such as Bermudagrass (Cynodon dactylon (L.) Pers.) and old world bluestems (Bothriochloa spp.) during summer [1]. However, the nutritive value of forage produced by these perennial grasses declines with maturity in early July, which can limit weight gain by stockers during summer without expensive protein supplements [2]. Based on the highly seasonal and variable growing conditions of the region [3], and the growth cycles of wheat and perennial warm-season grasses, there is no single crop with the potential to provide high quality forage year-round.

Alternate forage sources with the ability to fill the quality void that occurs during late-summer need to be explored to enhance the effectiveness of forage-stocker systems in the SGP. About 7000 plant species are cultivated across the world, but only $20 \%$ have been used to satisfy $90 \%$ of food requirements for humans [4]. The remaining species have been underutilized or neglected for different reasons. Bringing these under-utilized alternate crops from such a broad base into forage-stocker production systems as forages could enhance the sustainability of such systems, increase agro-ecosystem diversity, and address different components of the USDA-ARS Grand Challenge [5].

Past research has defined the potential use of some grain legumes as forage sources during summer [1] [6] [7] [8] [9] [10]. However, many of the tested legumes have significant amounts of large-diameter, low digestibility stems in their aboveground biomass which limits their applicability for grazing [8]. Thus, there is a need for additional exploration to define more effective novel legume species as summer forage. Selection of an appropriate species also requires consideration of the prevailing agro-climatic conditions of the SGP. The region frequently encounters prolonged droughts, and amount and occurrence of summer rainfall are highly erratic [3]. Irrigation is not an option for most producers in the region, and those producers with irrigation are facing increasing limitations to the availability of ground water [11]. Plant species capable of performing on variable and low amounts of soil moisture with minimal effects on subsequent wheat crops might fit well for summer crops. Furthermore, it would be advantageous to identify species with spreading-type growth forms that might also be used as cover crops or green manures, to reduce moisture loss, lower soil temperature, avoid soil erosion, and increase mineral $\mathrm{N}$ availability for the subsequent winter wheat.

Mothbean is an annual summer legume primarily grown as multi-purpose crop in the arid/desert regions of India due to its high heat and drought tolerance. It provides highly nutritious grains for human consumption, forage for cattle, and a green cover for soil. Mothbean grain is a good source of protein (23\%), essential amino acids, carbohydrates, fiber, minerals, and vitamins which makes it a good source of nutrition for human diets [12]. Growing mothbean 
could boost the supply of food and quality forage in arid and semi-arid regions across the world [13]. The growth form of mothbean is prostrate, vining and semi-trailtype which helps in conserving soil moisture, lowering soil temperature, and reducing soil erosion. As a legume, mothbean can also improve soil nutrition through nitrogen fixation.

Exploration of the potential forage use of mothbean was started in the US in the early $20^{\text {th }}$ century. A fresh mothbean forage yield of $4.4 \mathrm{Mg} \cdot \mathrm{ha}^{-1}$ was measured in northwest Texas, though without seed set [14]. In the same period, yields

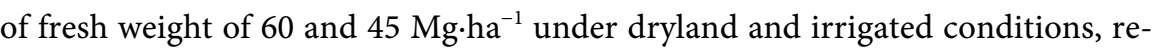
spectively, were measured near Fresno, California [15]. They [15] also reported a grain yield of $198 \mathrm{~kg} \cdot \mathrm{ha}^{-1}$ from a study near Davis, California. Thereafter, the forage potential of this crop was neglected in the US for unknown reasons, and no accounts on its forage productivity and nutritive value are available. Recently, grain yields ranging from 55 to $468 \mathrm{~kg} \cdot \mathrm{ha}^{-1}$ for 54 lines of mothbean that were reported in the eastern US.

The short growth cycle, food and forage potential, and soil conservation ability of mothbean suggest it may have the capacity to serve as a summer forage crop within the forage-stocker management systems used in the SGP. However, there is need to evaluate the capacity of genetic lines from different parts of the world for their adaptability and yields when grown under SGP's agrometeorological conditions. The objectives of this study were to examine the adaptability of ten mothbean lines to growing conditions in the central region of the SGP, quantify their grain and forage yields, and define their potential nutritive value as forage and green manure.

\section{Materials and Methods}

\subsection{Experiment Site and Its Characteristics}

This field study was conducted during the 2017 summer growing season (June through September) at the USDA-ARS Grazinglands Research Laboratory, near El Reno, OK $\left(35^{\circ} \mathrm{N}, 98^{\circ} \mathrm{W}\right.$, elevation $\left.414 \mathrm{~m}\right)$. Soil at the experiment site is described as Brewer silty clay loams (fine, mixed, superactive, thermic Pachic Udertic Argiustolls), with low permeability $\left(0.2-1.5 \mathrm{~cm} \cdot \mathrm{h}^{-1}\right)$, moderately well drained, $0 \%-1 \%$ slope, rarely flooded, and a pH of 6.9 [16]. Historical management of site involved growing wheat as a cover crop during the 10 years prior to the study by conventional tillage. The study site was conventionally tilled through a combination of disking (twice), rototilling (once), and culti-packing prior to planting. The amount of rainfall received during the growing season was $528 \mathrm{~mm}$, with a variable pattern of distribution (Figure 1). In contrast, the long-term (1994-2017) average precipitation for this period was $351 \mathrm{~mm}$. Average daily maximum and minimum temperatures (Tmax and Tmin, respectively) during the growing season were $31^{\circ} \mathrm{C}$ and $18^{\circ} \mathrm{C}$, respectively, which were approximate to the long-term averages. 


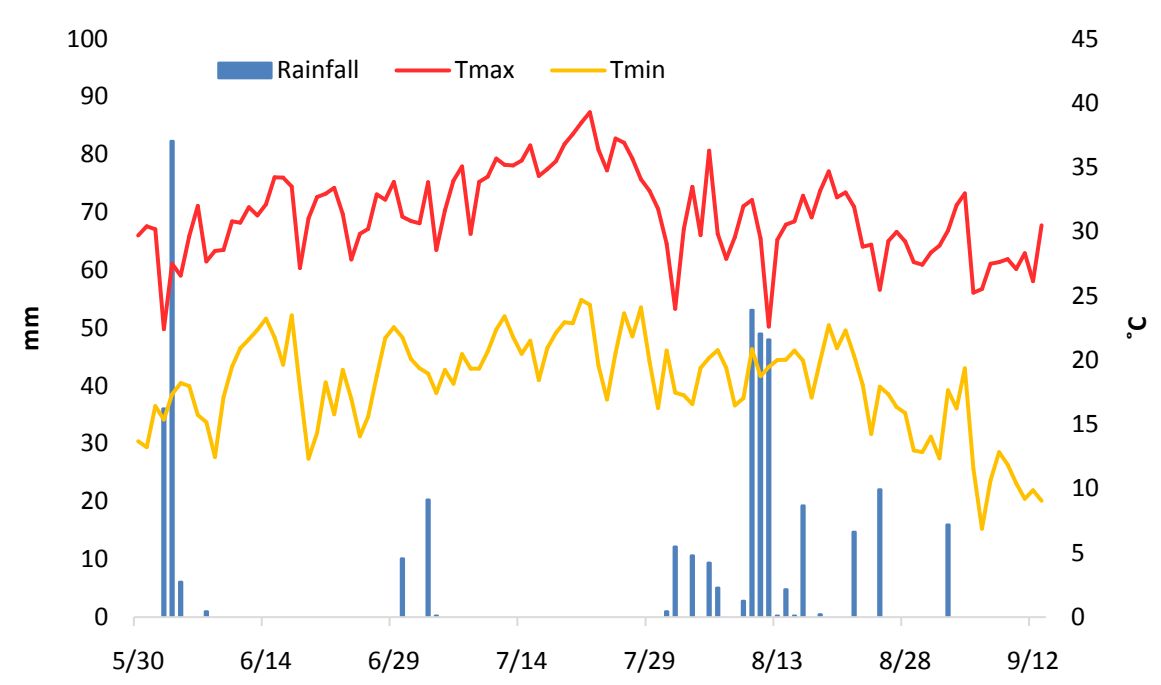

Figure 1. Rainfall and temperature encountered during the summer growing season of 2017 at El Reno, OK. $\mathrm{T}_{\max }$ and $\mathrm{T}_{\min }$ signify the daily maximum and daily minimum temperatures, respectively.

\subsection{Treatments and Agronomic Practices}

Ten lines of mothbean (25 seeds/line) were obtained from the USDA-ARS Plant Genetic Resources Conservation Unit, Griffin, GA (Table 1). Six lines (PI 271400, PI 271488, PI 288582, PI 288804, PI 288809, and PI 288810) are originally from India, two lines (PI 365427 and PI 426980) are from Pakistan, and PI 223521 and PI 372355 are originally from Afghanistan and Yemen, respectively. Most of the lines originated at more southerly latitudes than the study site. Experimental plots consisted of an individual row assigned to each line, spaced 60 $\mathrm{cm}$ apart. Seeds of each line were inoculated with cowpea-type Rhizobium spp. and hand planted $2 \mathrm{~cm}$ deep at $30 \mathrm{~cm}$ plant spacing on 30 May. Dry granular 18-46-0 fertilizer was applied at the rate of $100 \mathrm{~kg} \cdot \mathrm{ha}^{-1}$ prior to planting to provide $\mathrm{P}$. Weed control was achieved by one hand weeding at 30 days after planting.

\subsection{Data Collection and Statistical Analysis}

Three locations along rows assigned to each line were randomly chosen for sampling at end of growing season (13 Sep 2017). Measurements of canopy height were taken from the soil surface to top of the canopy for each plot prior to harvesting. Samples of aboveground biomass were collected on the same day by clipping $0.5-\mathrm{m}$ row lengths from each plot and fresh weights of samples were determined. All plant biomass related to plants within sampled row lengths were identified and included in samples. All samples were dried in a forced-air oven $\left(60^{\circ} \mathrm{C}\right)$ to a constant weight and dry biomass was calculated. Pods were separated and threshed to obtain grain yield stored for use in future experiments. The forage component (leaf and stem) of each sample was ground to pass a 2-mm screen in a Wiley mill, and stored at room temperature for laboratory analyses. Total $\mathrm{N}$ and carbon (C) concentrations were determined by flash combustion 
Table 1. Characteristics of ten mothbean lines from the USDA-ARS Plant Genetic Resources Conservation Unit grown at El Reno, OK, as described by the Germplasm Resources Information Network (GRIN).

\begin{tabular}{|c|c|c|c|c|c|c|c|}
\hline \multirow{3}{*}{ GRIN ID } & \multicolumn{3}{|c|}{ Source } & \multirow{3}{*}{$\begin{array}{c}\text { Growth } \\
\text { Habit }\end{array}$} & \multirow{3}{*}{$\begin{array}{c}\begin{array}{c}\text { Plant } \\
\text { Height }\end{array} \\
(\mathrm{cm})\end{array}$} & \multirow{3}{*}{$\begin{array}{l}\text { Grain } \\
\text { Yield }\end{array}$} & \multirow{3}{*}{$\begin{array}{l}\text { Received } \\
\text { (Year) }^{\star *}\end{array}$} \\
\hline & Location & Latitude & $\begin{array}{c}\text { Plant } \\
\text { Maturity }\end{array}$ & & & & \\
\hline & & ${ }^{\circ} \mathrm{N}$ & (days) & & & & \\
\hline PI 223521 & Afghanistan & 34.7 & 90 & Semi-prostrate & $\mathrm{NA}^{*}$ & Medium & 1955 \\
\hline PI 271400 & India & 20.0 & 110 & Prostrate & 20 & Limited & 1961 \\
\hline PI 271488 & India & 26.4 & 130 & Prostrate & 43 & High & 1961 \\
\hline PI 288582 & India & 28.3 & 85 & Prostrate & 25 & Medium & 1963 \\
\hline PI 288804 & India & 23.0 & 130 & Prostrate & 35 & High & 1963 \\
\hline PI 288809 & India & 31.7 & 90 & Prostrate & 25 & Low & 1963 \\
\hline PI 288810 & India & 23.4 & 130 & Prostrate & 40 & High & 1963 \\
\hline PI 365427 & Pakistan & 34.8 & 90 & Prostrate & 23 & Medium & 1971 \\
\hline PI 372355 & Yemen & 14.1 & 90 & Prostrate & $\mathrm{NA}^{*}$ & Limited & 1972 \\
\hline PI 426980 & Pakistan & 32.6 & 75 & Prostrate & 20 & High & 1978 \\
\hline
\end{tabular}

https://npgsweb.ars-grin.gov/gringlobal/accessiondetail.aspx?id=1218458 (accessed 15 February 2017). ${ }^{*} \mathrm{NA}=$ Not Available. ${ }^{* *}$ Year in which the GRIN received seed.

and analyzing gases evolved from samples in an auto-analyzer (Model Vario Macro, Elementar Americas, Inc., Mt. Laurel, NJ).

Total amounts of accumulated $\mathrm{N}$ in aboveground biomass $\left(\mathrm{kg} \mathrm{N} \mathrm{ha}^{-1}\right)$ were calculated from amount of biomass collected and $\mathrm{N}$ concentrations in biomass. $\mathrm{CP}$ was calculated by multiplying total $\mathrm{N}$ concentrations by 6.25 . Percentage of NDF and ADF in biomass samples were determined by using a batch processor [17] [18]. IVTD was determined using techniques for a Daisy Digester (Ankom Technology Corp., Fairport, NY).

Measurements and biomass samples were collected randomly (independently) within each row (line of mothbean) and considered as pseudo-replicates [19]. Data were analyzed using one-way analyses of variance (ANOVA) to identify the differences among the 10 lines for yields, CP, NDF, ADF, IVTD and accumulated $\mathrm{N}$ using proc GLM in SAS version 9.4 [20]. Differences among mean responses were defined by Least Significance Difference (LSD) post hoc test at 5\% significance level [21].

\section{Results and Discussion}

\subsection{Adaptability}

Excellent emergence (>90\%) was visually observed with all 10 lines after $124 \mathrm{~mm}$ rain had accumulated three days after planting. Since these seeds were $40-60$ years old, successful emergence revealed the potential of mothbean seeds held in long-term storage to sustain germination without any seed treatments. However, after the rainfall events occurred during the first week post-planting, a pro- 
longed dry period occurred in June-July, with only $30 \mathrm{~mm}$ rain received, followed by over $250 \mathrm{~mm}$ in August (Figure 1). Most of the lines of mothbean showed slow growth throughout the dry period, but stayed green. Only PI 288809 failed to survive due to unknown reasons. All lines of mothbean reached physiological maturity within 90 - 100 days after planting except PI 372355, which did not flower probably due to its source from much southerly latitude (Table 1).

\subsection{Canopy Height}

Canopy height, dry biomass, and grain yields of mothbean lines differed $(p<$ $0.05)$. The final canopy height of mothbean lines was found to be within a range of $20-32 \mathrm{~cm}$ (Table 2). The PI 223521 line showed maximum canopy height among the nine surviving lines due to its different growth habit, which is semi-prostrate. This growth form was observed visually in the field and also reported by Germplasm Resources Information Network (GRIN) database (Table 1). The lowest canopy height was recorded for PI 288804 among the nine lines, which was not different $(p>0.05)$ from that of PI 288582 and PI 372355. The canopy heights of PI 271488, PI 288804, and PI 288810 were found to be lower than the values reported in the GRIN database (Table 1).

\subsection{Grain Yield}

Grain yield varied among mothbean lines from 91 to $1040 \mathrm{~kg} \cdot \mathrm{ha}^{-1}$ (Table 2),

Table 2. Canopy height, dry biomass, and grain yield of ten lines of mature mothbean at El Reno, OK.

\begin{tabular}{|c|c|c|c|c|}
\hline \multirow{2}{*}{ GRIN ID } & \multirow{2}{*}{ Source location } & \multirow{2}{*}{$\begin{array}{c}\text { Canopy Height } \\
(\mathrm{cm})\end{array}$} & \multirow{2}{*}{$\begin{array}{c}\text { Grain Yield } \\
\left(\mathrm{kg} \cdot \mathrm{ha}^{-1}\right)\end{array}$} & \multirow{2}{*}{$\begin{array}{c}\text { Dry Biomass } \\
\left({\left.\mathrm{Mg} \cdot \mathrm{ha}^{-1}\right)}^{-1}\right.\end{array}$} \\
\hline & & & & \\
\hline PI 223521 & Afghanistan & $31.7 \mathrm{a}$ & $427.2 \mathrm{~cd}$ & $7.30 \mathrm{c}$ \\
\hline PI 271400 & India & $24.1 \mathrm{bc}$ & $98.5 \mathrm{e}$ & $8.67 \mathrm{bc}$ \\
\hline PI 271488 & India & $24.5 \mathrm{bc}$ & $1040.5 \mathrm{a}$ & $13.49 \mathrm{ab}$ \\
\hline PI 288582 & India & $21.6 \mathrm{~cd}$ & $652.7 \mathrm{bc}$ & $18.00 \mathrm{a}$ \\
\hline PI 288804 & India & $20.3 \mathrm{~d}$ & $189.4 \mathrm{de}$ & $11.14 \mathrm{bc}$ \\
\hline PI 288809 & India & - & - & - \\
\hline PI 288810 & India & $24.1 \mathrm{bc}$ & $551.6 \mathrm{bc}$ & $18.11 \mathrm{a}$ \\
\hline PI 365427 & Pakistan & $25.8 \mathrm{~b}$ & $91.6 \mathrm{e}$ & $11.79 \mathrm{bc}$ \\
\hline PI 372355 & Yemen & $21.5 \mathrm{~cd}$ & - & $11.20 \mathrm{bc}$ \\
\hline PI 426980 & Pakistan & $25.4 \mathrm{~b}$ & $848.4 \mathrm{ab}$ & $8.99 \mathrm{bc}$ \\
\hline Mean & & 24.4 & 433.3 & 12.07 \\
\hline$p$-value & & $<0.0001$ & $<0.0001$ & 0.0051 \\
\hline LSD & & 2.96 & 319.06 & 5.55 \\
\hline
\end{tabular}

Values within each column followed by same letter(s) are not different according to least significance difference (LSD) test $(p \leq 0.05)$. 
which was overall higher than the yield range reported in the eastern US reported [22]. The PI 271488 and PI 426980 lines showed higher grain production, which was in agreement with the GRIN database (Table 1), while lower grain production was observed for PI 365427, PI 271400, and PI 288804. Grain production of all other lines matched the yields stated by GRIN, except PI 288804, PI 288810, and PI 365427, which were found to be lower (Table 2). In regions like the SGP, grain production is not likely to be as important as forage production. However, if mothbean can be used as forage resource in the SGP, producers will need a source of seed for planting. Sufficient seed production would make use of mothbean in the region feasible and results in improved efficiency on farming operations. Viable grain yields could also allow SGP producers the opportunity to meet a growing demand for mothbean as a food grain in the future as the human population continues to grow.

\subsection{Forage Yield}

There were no reports on forage yield for any of the chosen mothbean lines in the GRIN database. In this study, yield of dry biomass of mothbean lines was found to be 7.3 - $18.1 \mathrm{Mg} \cdot \mathrm{ha}^{-1}$ (Table 2). The PI 288810 line produced the greatest amount of biomass among the nine lines, though the yields of PI 271488 and PI 288582 were similar. These results were in agreement with the forage yield of mothbean lines reported during the early $20^{\text {th }}$ century [15]. In comparison, the lowest yields during our study were observed for PI 223521, with low yields by PI 271400, PI 288804, PI 365427, and PI 426980 that were similar (Table 2). The amount of dry biomass produced by all lines were above levels $\left(1.1 \mathrm{Mg} \cdot \mathrm{ha}^{-1}\right)$ required to avoid any limitations on forage availability that could affect intake by yearling cattle on pasture [23].

\subsection{Nutritive Value of Forage and Its Comparison to Other Forages}

Differences were noted for $\mathrm{CP}$ and NDF concentrations among the mothbean lines (Table 3). In contrast, concentrations of ADF and IVTD among lines were similar. The CP content of mothbean lines at maturity ranged between $10.8 \%$ 14.6\%. Among lines, higher CP was observed in PI 271488 followed by PI 372355, PI 223521, PI 271400, and PI 288804; however, these lines were not different from each other $(p<0.05$; Table 3$)$. Furthermore, the average CP values of the top six lines varied only $1.62 \%$ from the highest (14.63\%) to the lowest (13.01\%). The CP concentration was numerically lower in PI 288582, followed by PI 365427, and PI 426980 and these lines were not significantly different from each other. The NDF concentration at maturity of tested lines ranged from $32.0 \%$ 41.7\% (Table 3). The PI 271488 line had numerically the lowest NDF concentration, but was only significantly different from PI 271400 , PI 365427 , PI 372355 , and PI 426980. There was no difference in ADF among the mothbean lines despite a range of $20.7 \%-29.6 \%$ (Table 3 ). The IVTD of all mothbeans was not 
Table 3. Forage nutritive value of whole plant biomass of 10 lines of mothbean at maturity.

\begin{tabular}{|c|c|c|c|c|c|}
\hline \multirow{2}{*}{ GRIN ID } & \multirow{2}{*}{$\begin{array}{l}\text { Source } \\
\text { location }\end{array}$} & $\mathrm{CP}$ & NDF & $\mathrm{ADF}$ & IVTD \\
\hline & & \multicolumn{4}{|c|}{ - } \\
\hline PI 223521 & Afghanistan & $13.85 \mathrm{ab}$ & $36.22 \mathrm{bcd}$ & 25.62 & 77.31 \\
\hline PI 271400 & India & $13.41 \mathrm{abc}$ & $38.20 \mathrm{abc}$ & 25.05 & 83.38 \\
\hline PI 271488 & India & $14.63 \mathrm{a}$ & $32.03 \mathrm{~d}$ & 20.73 & 78.95 \\
\hline PI 288582 & India & $10.83 \mathrm{~d}$ & $36.18 \mathrm{bcd}$ & 23.54 & 80.85 \\
\hline PI 288804 & India & $13.09 \mathrm{abc}$ & $35.93 \mathrm{bcd}$ & 24.13 & 81.06 \\
\hline PI 288810 & India & $13.01 \mathrm{abcd}$ & $34.91 \mathrm{~cd}$ & 22.21 & 81.36 \\
\hline PI 365427 & India & $11.31 \mathrm{~cd}$ & $40.47 \mathrm{ab}$ & 28.01 & 78.29 \\
\hline PI 372355 & Pakistan & $14.49 \mathrm{a}$ & $41.67 \mathrm{a}$ & 29.59 & 73.06 \\
\hline PI 426980 & Yemen & $12.23 \mathrm{bcd}$ & $38.13 \mathrm{abc}$ & 26.42 & 83.10 \\
\hline Mean & & 12.98 & 37.08 & 25.03 & 79.71 \\
\hline$p$-value & & 0.022 & 0.034 & NS & NS \\
\hline LSD & & 2.23 & 5.19 & - & - \\
\hline
\end{tabular}

Values within each column followed by same letter(s) are not different according to least significance difference (LSD) test $(p \leq 0.05)$. NS $=$ Non-significant at $p>0.05$.

different $(p<0.05)$ from each other and ranged between $73 \%-84 \%$ at maturity. Generally, measures of nutritive value of forage were reported to decline with increasing maturity in most of the forage legumes tested in the SGP [6] [7] [10]. However, the nutritive value of tested mothbean lines at maturity was still above requirements (10.5\% CP and $67.5 \%$ IVTD) of cattle weighing $300 \mathrm{~kg}$ and gaining $1 \mathrm{~kg} \cdot \mathrm{d}^{-1}[23]$.

Based on our results (Table $2 \&$ Table 3), PI 271488 appeared to be an interesting candidate for the SGP region. The PI 271488 line not only showed high grain yield production, but also equal or superior forage yield and nutritive value compared to the other lines. A generalized comparison of nutritive value of mothbean i.e. PI 271488 forage with that of soybean (Glycine max) [6], guar (Cyamopsis tetragonoloba) [8], and pigeon pea (Cajanus cajan) [7] at maturity is presented in Table 4, though weather and soil conditions were different across the studies. In the past research conducted in the SGP, both guar and pigeon pea produced high forage yields on limited moisture but their low digestibility stems appeared to be a limitation to grazing [6] [7] [8]. In this study, plant biomass of mothbean appeared to be superior to guar and pigeon pea in both CP and IVTD.

Soybean has been used as a control for forage quality comparisons in many studies testing annual legumes as summer forage. Under weather and soil conditions similar to this study, some annual legumes outperformed soybean in some, but not all aspects of forage quality except lablab (Lablab purpureus (L.) Sweet) [9]. However, amount of biomass production by both soybean and lablab was limited by low precipitation. In contrast, mothbean lines evaluated in this study persisted through a continuous 8-week drought in the current study and still 
Table 4. Comparisons of forage quality of mothbean, soybean, guar, and pigeon pea at maturity.

\begin{tabular}{ccccc}
\hline Forage traits & Mothbean & Soybean & Guar & Pigeon pea \\
\hline CP\% & $14.6(0.3)$ & $17.5(0.6)$ & $9.6(0.2)$ & $13.9(0.5)$ \\
IVTD\% & $78.9(3.3)$ & $75.0(1.2)$ & $52.5(1.5)$ & $57.2(0.6)$ \\
References & & {$[6]$} & {$[8]$} & {$[7]$} \\
\hline
\end{tabular}

*Values in the parentheses represent standard errors of means.

produced good amounts of biomass. Therefore, mothbean could be a better fit in limited moisture conditions of the SGP. Although, it was comparatively lower in CP than soybean, the IVTD of mothbean forage was higher (Table 4). Mothbean pods were separated from the forage samples in this study, and have approximately 18\% - 19\% CP (G. Baath, unpublished data). Therefore, whole plant biomass of mothbean (including pods) in a pasture setting would have $\mathrm{CP}$ concentrations that were competitive to soybean. However, the function of mothbean in a grazed setting needs to be evaluated to define its capacity to support stocker growth in the region.

\subsection{Green Manure Potential}

In this study, the lines of tested mothbean had a vigorous trailing and viney growth habit, which completely covered the soil with long trailing stems and leaves, and functioned to help control weed growth. Amounts of total $\mathrm{N}$ accumulated in aboveground biomass were different among mothbean lines and ranged from 163 - $316 \mathrm{~kg} \cdot \mathrm{ha}^{-1}$ (Table 5). The PI 288810, PI 271488, and PI 288582 lines accumulated comparatively high amounts of $\mathrm{N}$ due to greater amounts of accumulated biomass. The $\mathrm{C}: \mathrm{N}$ ratio of mothbean lines ranged from 16:1 to 22:1 with the PI 288582, PI 288804, PI 365427, and PI 426980 lines having higher ratios than the remaining lines (Table 5).

Earlier research on green manure applications in the SGP found that soybean and lablab accumulated 65 to $80 \mathrm{~kg} \mathrm{~N} \mathrm{ha}^{-1}$ by the end of growing season but were not effective at enriching soil $\mathrm{N}$ [9]. Similar results were reported in a study testing soybean (accumulated $48 \mathrm{~kg} \mathrm{~N} \mathrm{ha}^{-1}$ ) as green manures in rotations of winter wheat grown for pasture and hay production in central Oklahoma [24]. The amounts of $\mathrm{N}$ accumulated and C:N ratios observed in this study indicate mothbean has potential to serve as a green manure, and provide large amounts of mineral $\mathrm{N}$ for subsequent crops of winter wheat. Further research on quantifying the agronomic benefits from mothbean-winter wheat rotation in the SGP can bring more insight on its green manure aspect.

\section{Conclusions}

Mothbean lines from different geographic locations (more southerly latitudes compared to Oklahoma) showed a range of adaptability to the agro-climatic conditions of the SGP. All mothbean lines, except PI 288809, tolerated the hot 
Table 5. Amount of accumulated $\mathrm{N}$ in aboveground biomass by mothbean lines and their $\mathrm{C}: \mathrm{N}$ ratio at maturity.

\begin{tabular}{cccc}
\hline \multirow{2}{*}{ GRIN ID } & Source location & Accumulated N & C:N \\
\cline { 3 - 4 } & & $\left(\mathrm{Kg}^{-} \mathrm{ha}^{-1}\right)$ & $16.81 \mathrm{c}$ \\
PI 223521 & Afghanistan & $163.3 \mathrm{c}$ & $18.11 \mathrm{bc}$ \\
PI 271400 & India & $184.0 \mathrm{c}$ & $16.13 \mathrm{c}$ \\
PI 271488 & India & $316.4 \mathrm{ab}$ & $21.92 \mathrm{a}$ \\
PI 288582 & India & $310.2 \mathrm{ab}$ & $18.57 \mathrm{abc}$ \\
PI 288804 & India & $229.0 \mathrm{bc}$ & $18.23 \mathrm{bc}$ \\
PI 288810 & India & $376.8 \mathrm{a}$ & $21.52 \mathrm{ab}$ \\
PI 365427 & India & $219.1 \mathrm{bc}$ & $16.71 \mathrm{c}$ \\
PI 372355 & Pakistan & $259.0 \mathrm{bc}$ & $19.56 \mathrm{abc}$ \\
PI 426980 & Yemen & $174.4 \mathrm{c}$ & 18.62 \\
Mean & & 248.0 & 0.0225 \\
$p$-value & & 0.0134 & 3.47 \\
LSD & & 117.1 & \\
\hline
\end{tabular}

Values within each column followed by same letter(s) are not different according to least significance difference (LSD) test $(p \leq 0.05)$.

and dry conditions that occurred during June-July and generated 7.3 - 18.1 $\mathrm{Mg} \cdot \mathrm{ha}^{-1}$ dry biomass in response to precipitation received during the later parts of the growing season. Tested lines of mothbean were also capable of producing grain at the more northerly latitude of the study site, though there was a wide range in production (91 to $1040 \mathrm{~kg} \cdot \mathrm{ha}^{-1}$ ). The higher forage and grain yields noted within the ranges of responses indicated some potential for genetic improvement that can provide lines more capable of generating both grain and forage.

This study has also provided a base-line for the nutritive value of forage produced by mothbean that was not available within the existing literature. Mothbean possessed medium amounts of $\mathrm{CP}$, low NDF and ADF concentrations and high IVTD at maturity, which highlights the capacity to support grazing by stocker cattle during summer in the SGP. The study also revealed the high green manure potential of mothbean as it generated large amount of $\mathrm{N}$ rich biomass that completely covered the soil. Future research should focus on evaluating mothbean within different crop settings to define its capacity as green manure or summer forage to support production of stocker cattle or as stored feed in the SGP.

\section{Acknowledgements}

The authors would like to recognize ARS technicians Kory Bollinger, Jeff Weik, and Cindy Coy for their assistance in managing experimental sites, and collecting, processing, and analyzing samples. Special thanks to USDA-ARS Grazinglands Research Laboratory for funding and providing the resources needed for 
this research. Mention of trade names or commercial products in this publication is solely for the purpose of providing specific information and does not imply recommendation or endorsement by the US Department of Agriculture. USDA is an equal opportunity provider and employer.

\section{References}

[1] Rao, S.C., Coleman, S.W. and Mayeux, H.S. (2002) Forage Production and Nutritive Value of Selected Pigeon Pea Ecotypes in the Southern Great Plains. Crop Science, 42, 1259-1263. https://doi.org/10.2135/cropsci2002.1259

[2] Phillips, W.A. and Coleman, S.W. (1995) Productivity and Economic Return of Three Warm Season Grass Stocker Systems for the Southern Great Plains. Journal of Production Agriculture, 8, 334-339. https://doi.org/10.2134/jpa1995.0334

[3] Schneider, J.M. and Garbrecht, J.D. (2003) A Measure of the Usefulness of Seasonal Precipitation Forecasts for Agricultural Applications. Transactions of the ASAE, 46, 257-267. https://doi.org/10.13031/2013.12976

[4] Chivenge, P., Mabhaudhi, T., Modi, A.T. and Mafongoya, P. (2015) The Potential Role of Neglected and Underutilised Crop Species as Future Crops under Water Scarce Conditions in Sub-Saharan Africa. International Journal of Environmental Research and Public Health, 12, 5685-5711. https://doi.org/10.3390/ijerph120605685

[5] USDA ARS (2017) Agricultural Research Service 2016 Report on Science. Washington DC.

https://www.ars.usda.gov/ARSUserFiles/00000000/NPS/OAA/2016\%20ARS\%20An nual\%20Report.pdf

[6] Rao, S.C. and Northup, B.K. (2009) Capabilities of Four Novel Warm-Season Legumes in the Southern Great Plains: Biomass and Forage Quality. Crop Science, 49, 1096-1102. https://doi.org/10.2135/cropsci2008.08.0499

[7] Rao, S.C. and Northup, B.K. (2012) Pigeon Pea Potential for Summer Grazing in the Southern Great Plains. Agronomy Journal, 104, 199-203.

https://doi.org/10.2134/agronj2011.0260

[8] Rao, S.C. and Northup, B.K. (2013) Biomass Production and Quality of Indian-Origin Forage Guar in Southern Great Plains. Agronomy Journal, 105, 945-950. https://doi.org/10.2134/agronj2012.0378

[9] Northup, B.K. and Rao, S.C. (2015) Green Manure and Forage Potential of Lablab in the US Southern Plains. Agronomy Journal, 107, 1113-1118.

https://doi.org/10.2134/agronj14.0455

[10] Northup, B.K. and Rao, S.C. (2016). Effects of Legume Green Manures on Forage Produced in Continuous Wheat Systems. Agronomy Journal, 108, 101-108. https://doi.org/10.2134/agronj15.0031

[11] Allen, V.G., Baker, M.T., Segarra, E. and Brown, C.P. (2007) Integrated Irrigated Crop-Livestock Systems in dry Climates. Agronomy Journal, 99, 346-360. https://doi.org/10.2134/agronj2006.0148

[12] USDA ARS (2016) USDA National Nutrient Database for Standard Reference: Release 28. USDA ARS, Washington DC.

[13] National Academy of Sciences (1979) Tropical Legumes: Resources for the Future. National Academies of Sciences, Washington DC.

[14] Conner, A.B. (1908) Forage Crops in Northwest Texas. Bulletin No. 103. Texas Agricultural Experiment Station. Texas A\&M University, College Station. 
[15] Kennedy, P.B. and Madson, B.A. (1925) The Mat Bean: Phaseolus aconitifolius. Agricultural Experiment Station, University of California, Berkeley, 4.

[16] USDA-NRCS (1999) Soil Survey of Canadian County, Oklahoma. Supplement Manuscript, USDA-NRCS and Oklahoma Agric. Exp. Stn., Stillwater.

[17] Goering, H.K. and Van Soest, P.J. (1970) Forage Fiber Analyses (Apparatus, Reagents, Procedures, and Some Applications). Agric. Handb. 379, USDA, Beltsville.

[18] Van Soest, P.J., Robertson, J.B. and Lewis, B.A. (1991) Methods for Dietary Fiber, Neutral Detergent Fiber, and Nonstarch Polysaccharides in Relation to Animal Nutrition. Journal of Dairy Science, 74, 3583-3597. https://doi.org/10.3168/jds.S0022-0302(91)78551-2

[19] Gomez, K.A. (1984) Statistical Procedures for Agricultural Research. Wiley, New York.

[20] SAS Institute (2013) SAS Institute Version 9.4.

[21] Steel, R.G.D. and Torrie, J.H. (1980) Principles and Procedures of Statistics: A Biometrical Approach. 2nd Edition, McGraw-Hill, New York.

[22] Bhardwaj, H.L. and Hamama, A.A. (2016) Evaluation of the US Mothbean Collection for Seed Yield Potential in Virginia and Nutritional Composition of Freshly Harvested Seed. HortTechnology, 26, 820-824. https://doi.org/10.21273/HORTTECH03432-16

[23] Coleman, S.W., Rao, S.C., Volesky, J.D. and Phillips, W.A. (2010) Growth and Nutritive Value of Perennial C 3 Grasses in the Southern Great Plains. Crop Science, 50, 1070-1078. https://doi.org/10.2135/cropsci2009.04.0177

[24] MacKown, C.T., Heitholt, J.J. and Rao, S.C. (2007) Agronomic Feasibility of a Continuous Double Crop of Winter Wheat and Soybean Forage in the Southern Great Plains. Crop Science, 47, 1652-1660. https://doi.org/10.2135/cropsci2006.10.0683 